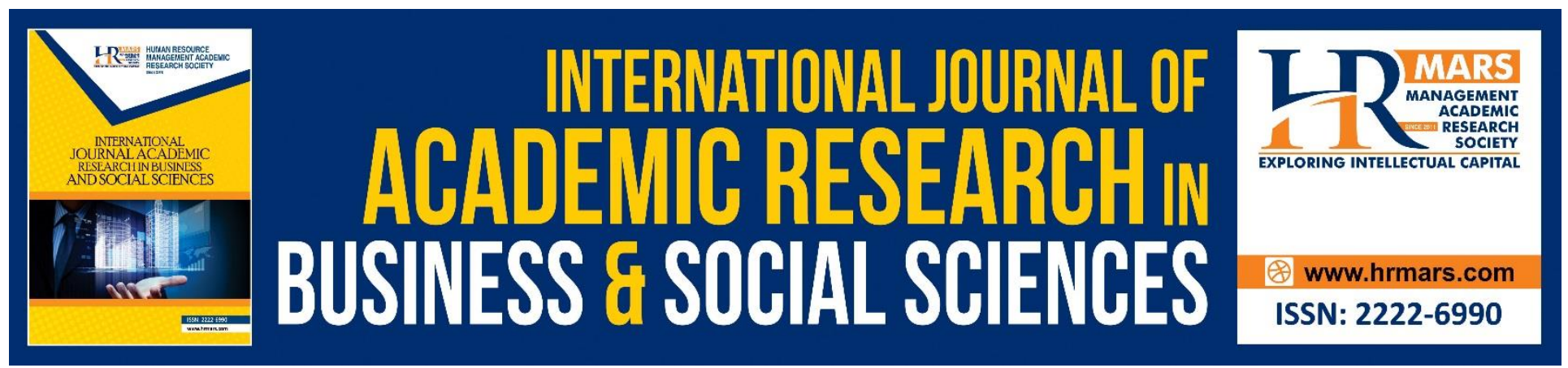

\title{
Muslim Consumers' Perceptions of Service Quality for Halal Food Service Industry
}

\author{
Munira Saaidin, Noor Raihan Ab Hamid and Siti Nurbayah
}

To Link this Article: http://dx.doi.org/10.6007/IJARBSS/v8-i9/4875

DOI: $\quad 10.6007 /$ IJARBSS/v8-i9/4875

Received: 17 August 2018, Revised: 06 Sept 2018, Accepted: 21 Sept 2018

Published Online: 28 Sept 2018

In-Text Citation: (Saaidin, Hamid, \& Nurbayah, 2018)

To Cite this Article: Saaidin, M., Hamid, N. R. A., \& Nurbayah, S. (2018). Muslim Consumers' Perceptions of Service Quality for Halal Food Service Industry. International Journal of Academic Research in Business and Social Sciences, 8(9), 1965-1974.

\section{Copyright: (C) 2018 The Author(s)}

Published by Human Resource Management Academic Research Society (www.hrmars.com)

This article is published under the Creative Commons Attribution (CC BY 4.0) license. Anyone may reproduce, distribute, translate and create derivative works of this article (for both commercial and non-commercial purposes), subject to full attribution to the original publication and authors. The full terms of this license may be seen

at: $\underline{\text { http://creativecommons.org/licences/by/4.0/legalcode }}$

Vol. 8, No. 9, September 2018, Pg. 1965 - 1974

Full Terms \& Conditions of access and use can be found at http://hrmars.com/index.php/pages/detail/publication-ethics 


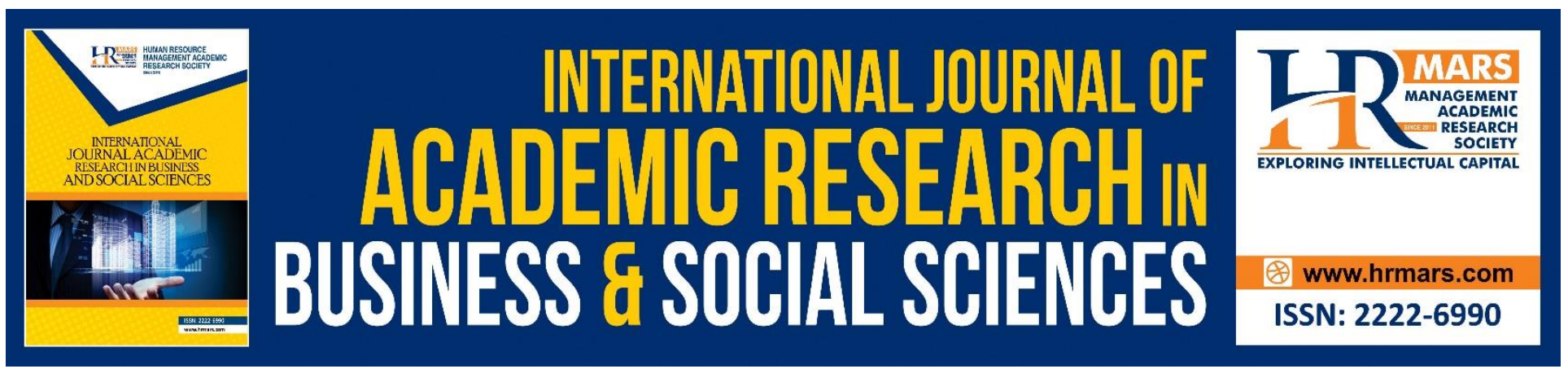

\title{
Muslim Consumers' Perceptions of Service Quality for Halal Food Service Industry
}

\author{
Munira Saaidin ${ }^{1}$, Noor Raihan Ab Hamid ${ }^{2}$ and Siti Nurbayah ${ }^{3}$ \\ ${ }^{1}$ School of Culinary Arts, UNITAR International University, Selangor 47301, Malaysia \\ 2,3Faculty of Business and Technology, UNITAR International University, Selangor 47301, Malaysia
}

\begin{abstract}
This study examines the influence of Muslim consumers' perceptions towards service quality in halal restaurants. The purpose of this study is to explore the factors why Muslim consumers patronize Halal restaurants as well as the assessment of service quality in Halal restaurants as this is important to identify the key attributes towards the service quality in Halal foodservice industry. Hence, this study stretch advantage for the foodservice operator when they are complying Halal certification to fulfil the demand for Halal certified restaurant. This paper investigates the key attributes of service quality from the perspectives of Muslim consumers and it had been explored via in-depth interviews. The in-depth interviews were being steered among selected Muslim consumers which had experienced dine-in in the Halal restaurant. Findings for the study divulge the important insight that attributes measured significant for the foodservice industry in the assessment of service quality by Muslim consumers. Future, this study also has prospective to supplement for the concept and theory of Halal service quality since there are very few literature or studies had been discovered.
\end{abstract}

Keywords: Halal restaurant, Muslim consumers, Halal service quality, Foodservice Operator, Halal Certification

\section{Introduction}

The important relationships of service quality, customer satisfaction, and purchasing behavior have thus been an important area of research (Pettijohn et al., 1997; Sivas and Baker-Prewitt, 2000). It is a common belief that improving service quality is imperative in a competitive environment of the service industry. In the restaurant businesses, service providers have begun to place greater emphasis on the quality of services by means of providing a pleasant dining experience to consumers. Moreover, the emergence of Halal services, which include Halal restaurants, intensifies the competition as the Halal restaurant businesses are dealing with a segment of consumers who have different needs and preferences from that of conventional consumers. In turn, consumers are likely to commit and patron a foodservice establishment or repurchase a food product (Qin and Prybutok, 2009; Hyun, 2010; Barber et al., 2011). Service is in the frontier for economies in the post 
manufacturing era. Ibrahim and Othman (2014) stated the foodservice sector is one component of the economy which complements the intention of Malaysia to become a Halal hub. Since quality is a tenet of foodservices, evaluation to ensure a competitive advantage to remain in the forefront of the Malaysian economy is indispensable. Malaysia is poised to be one of the leading nations in the Halal industry. From the view Halal restaurant business, there is an upward trend in obtaining Halal certification from both Muslim and non-Muslim restaurant owners. The growth of Halal restaurants is driven by the escalating demand from Muslim consumers. Simultaneously, from the consumers' perspective there seems to be an increasing awareness of Halal food service from Muslims consumers.

In fact, Abdullah et al., (2012) had in their works found and suggested specifically the halal component to be embedded in the framework for a successful Malaysian foodservice industry. Thus, in today's organization, effort need to be paid to ensure continuous improvement and breakthrough in quality to meet the customers' expectation and requirement. This is especially true in the foodservice organizations where service delivery is typically important to win and sustain customers (Ibrahim \& Othman, 2014). These scenario calls for restaurant managers to fully understand the behavior of Muslim consumers. This study can be utilized to evaluate the service quality of Halal restaurants. Saaidin et al., (2016) stated Halal certification is very prevalent in the hospitality industry as it promotes the importance of restaurant managers having knowledge of Muslim's dietary restrictions, sensitivities and religious practices.

\section{Literature Review}

This section discusses about the service quality and Halal restaurant

\section{Service Quality}

Parasuraman et al. (1988) describe service quality as an attitude developed by customers because of an encounter with a service firm. Past researches presented in a restaurant context such as DINESERV (Stevens et al, 1995) and DINESCAPE (Ryu \& Jang, 2008) alleged that patrons depend on tangible and intangible cues to evaluate the quality of the services. Tangible cues refer to the food quality (taste and presentation) and physical equipment while the latter involves among others, staff services (responsiveness, courtesy) and ambience of the restaurants (Sulek \& Hensley, 2004). Furthermore, these studies conclude that food quality and service rendered by employees as vital attributes that influence guest's assessment of overall service quality of restaurants (Marinkovic, 2014). According to Gayatri, Hume and Mort (2011) in their study had investigated the role of Islamic culture in service quality by interviewing 35 respondents sourced from airline, retail, hotel and restaurant industries where they found two main factors namely Islamic and service quality general factors. In other words, the closeness between Islamic culture and service quality are consistent.

More specifically, the fundamental factors that contribute to customer satisfaction in restaurants include the food (hygiene, balance, and healthiness), physical provision (layout, furnishing, and cleanliness), the atmosphere (feeling and comfort), and the service received (speed, friendliness, and care) during the meal experience (Johns \& Pine, 2002). 


\section{Halal Restaurant (Foodservice)}

As customers become more sophisticated, the owner of the restaurants needs to be more focused on the quality of their products, which requires emphasis on the service, food and drinks of halal products. Saaidin et al., (2016) wrote that the preparation and handling of Halal food is based on quality, sanitary and safety considerations and these are the fundamental requirement for food products and trade in Malaysia. This means that the products and services used for front of the house and back of the house must be strictly in accordance with the Syariah requirements. This is significantly prompting consumers' buying intention.

Halal restaurant (food service) is premised on the concept of Halalan Toyyiban (permissible and good for consumption) that is, serving food and beverages in accordance with the principles of the Islamic laws, also known as Sharia. Halalan Toyyiban concerns the process of food production from the farm (animal slaughtering) to food service, that involves the preparation and presentation (for example pork-and alcohol-free ingredients, food hygiene,) as determined by the Sharia (Ab Hamid et al., 2016). Research in the past incline to be narrow in scope as they deal either on attitude or purchase intentions and mostly focused on Halal products (for example, Mukhtar \& Butt (2012); Hamdan et al., (2013)). As the scope of the Halal industry encompasses to services including Halal restaurants, a study to gain a better understanding of service quality assessment from Muslim consumers is justified.

\section{Methodology}

For this study, a qualitative method was employed in this research as it seeks to obtain indepth answers to the "why" question rather than "what" (Yin, 2003). The inclusion criteria to obtain information included sampling from a subset of Muslims, average social class standing, age ranging from 20 to 60. This research employed the verbal protocol method to conduct in-depth interviews of consumers. Payne,(1994); Berne, (2004) stated verbal protocol method is a diagnostic tool in the study of consumer judgment and decision-making process. (Kuusela and Paul, 2000; Ericsson and Simon, 1984) as well as consumer problem solving process (Ericsson and Simon, 1984). Since the study pursues to address the Muslim consumers' perceptions of service quality for Halal restaurants, the respondents were from the Muslims consumers in the two cities in Malaysia namely Kuching and Kota Bharu. - Kuching is a highly multi-culture and religion city in Malaysia and Kota Bharu is a city known as a conservative-Muslim state of Malaysia (Taib \& Gill, 2012). Total respondents were 13 persons. The researcher asked similar questions to all interviewees and probing whenever needed, which helped in gathering ironic data, most beneficial for exploratory studies. (Jan et al., 2011). The interview-duration for the focus group was approximately one hour and was tape-recorded. The interviews were transcribed verbatim.

\section{Findings}

\section{Respondents Profile}

The demographic profile of the respondents is shown in Table 1. Seven Muslim respondents have patronized Halal restaurants for more than three years (88\%). 
INTERNATIONAL JOURNAL OF ACADEMIC RESEARCH IN BUSINESS AND SOCIAL SCIENCES

Vol. 8, No. 9, Sept. 2018, E-ISSN: 2222-6990 @ 2018 HRMARS

Table 1: Details Profiles of Muslim Respondents

\begin{tabular}{|c|c|c|c|c|}
\hline Respondent & Age & Gender & Area & $\begin{array}{c}\text { Years of patronizing } \\
\text { Halal restaurant }\end{array}$ \\
\hline Respondent 1 & $20-30$ & Female & Kuching & Less Than a Year \\
\hline Respondent 2 & $20-30$ & Male & Kuching & More Than 3 Years \\
\hline Respondent 3 & $20-30$ & Male & Kuching & Less Than a Year \\
\hline Respondent 4 & $20-30$ & Female & Kuching & Less Than a Year \\
\hline Respondent 5 & $20-30$ & Female & Kuching & Less Than a Year \\
\hline Respondent 6 & $20-30$ & Female & Kuching & Less Than a Year \\
\hline Respondent 7 & Above 50 & Male & Kuching & More Than 3 Years \\
\hline Respondent 8 & Above 50 & Male & Kuching & More Than 3 Years \\
\hline Respondent 9 & Above 50 & Female & Kota Bharu & More Than 3 Years \\
\hline Respondent 10 & Above 50 & Female & Kota Bharu & More Than 3 Years \\
\hline Respondent 11 & Above 50 & Female & Kota Bharu & More Than 3 Years \\
\hline Respondent 12 & Above 50 & Female & Kota Bharu & More Than 3 Years \\
\hline Respondent 13 & $20-30$ & Female & Kota Bharu & Less Than A Year \\
\hline
\end{tabular}

\section{Data Collection and Analysis}

A thorough content analysis using manual procedures was applied as suggested by Krippendorff (2004). It began with identifying the recorded information that was important for developing themes and interrelationships following theoretical and conceptual suggestions. In this stage, transcripts were prepared from the recorded focus group sessions. Finally, the data were analyzed via thematic analysis by referring to a study conducted by Ong et al., (2014).

The results found that the key attributes of service quality from Muslim respondents choose to dine-in in the halal restaurant based on four main headings; assurance, quality of food, cleanliness, staff service quality.

Table 2. Attributes of Service Quality from Muslim respondents

\begin{tabular}{|c|c|c|c|c|}
\hline Respondent & Assurance & Quality of food & Cleanliness & $\begin{array}{c}\text { Staff service } \\
\text { quality }\end{array}$ \\
\hline Respondent 1 & $x$ & $x$ & & \\
\hline Respondent 2 & $x$ & & $x$ & \\
\hline Respondent 3 & & $x$ & $\mathrm{X}$ & \\
\hline Respondent 4 & $x$ & & & \\
\hline Respondent 5 & $x$ & & & $x$ \\
\hline Respondent 6 & & $x$ & & \\
\hline Respondent 7 & $x$ & & & \\
\hline Respondent 8 & $x$ & & $x$ & \\
\hline Respondent 9 & $x$ & $x$ & & \\
\hline Respondent 10 & $x$ & & $x$ & \\
\hline Respondent 11 & $x$ & & & $x$ \\
\hline Respondent 12 & $x$ & & & $x$ \\
\hline Respondent 13 & $x$ & & $X$ & \\
\hline
\end{tabular}




\section{Assurance}

Majority of the respondents were mentioned that the level of assurance provided by the Halal restaurants is one of the main factors which influence their assessment of service quality. Therefore, the service providers that provide the proper facilities or give the more attention towards the details are more in demand for Muslim consumers. The following statements describe their expressions:

[...] when I see a restaurant, which carries a Halal logo I feel safe to dine in it (R1).

[...] I am confident that the restaurant follows the processes according to the Sharia' (R14)

[...] I will not dine at a restaurant which I am not sure if it is a Halal restaurant...assurance is important to me (R16)

As reported by Abdul et al. (2009) Muslim consumers in Malaysia are more concerned with the halal logo and food ingredients than other major religious groups. According to JAKIM (a local government authority producing Halal certificates) the demand for Halal certification is on the rise in Malaysia including from the non-Muslim service providers. Therefore, the first proposition follows:

RP1: Assurance is a significant factor influencing consumer's assessment of service quality in Halal restaurants.

\section{Quality of food}

The major of the participants mentioned they preferred to dine-in halal restaurant due to the quality of food served. Several criteria which influenced their selection to dine-in halal restaurant was mentioned by the respondents. Many of them considered the quality as of food safe to be eaten, ingredient used and good taste. The following statements describe their expressions:

[...] I prefer to choose halal restaurant because of the taste of the food (R2)

[...] I decide to dine-in in halal restaurant because of the ingredients used are halal (R8)

$[\ldots .$. ".... safe to eat. No syubhah" (R7).

RP2: Quality of food has significant factors influencing Muslim consumers in service quality in Halal restaurants.

\section{Cleanliness}

Cleanliness or hygiene is one of the factors perceived as important by Muslim and non-Muslim patrons. Some of the respondents asserted the followings:

Cleanliness is an important part of our faith [...] (R8)

Halal restaurants must portray a good image of Islam...then the facilities should be clean [...] (R15)

Based on these expressions, it is proposed that:

RP3: Cleanliness is a significant factor influencing consumer's assessment of service quality in Halal restaurants. 


\section{Staff Service Quality}

The quality of service delivered by restaurants' staff is also another factor influencing the assessment of service quality by Muslim consumers. Some respondents indicated that:

[...] staff who are willing to assist with our special requests makes us feel appreciated (R5)

[...] the serving staff are polite (R11)

According to Ramanathan (2016) when customer's involvement in the entire dining process is high the ability of service personnel in delivering the service efficiently is crucial. In addition, during a visit to the restaurant, customer experiences the product, service and ambience in the establishment (Samyak, 2012). In the restaurant, the service delivery process would begin by checking in at the reception of the restaurant and end with presenting the bill to the customer and saying good-bye (checking-out). Hence it is proposed that:

RP4: Service from employee is a significant factor influencing consumer's assessment of service quality in Halal restaurants.

\section{Conclusions}

This study provides a platform for future research in the Halal service quality in foodservice industry. Above all, Muslim consumers demand for Assurance that the food they consume are halal. Muslim consumers would feel confident in dining when the Halal logo or certification of Halal is visible. Generally, Muslim consumers place great consideration on Cleanliness and food quality in their assessment of service quality. Food hygiene and safe to be consumed are imperatives of service quality especially for Halal restaurants as Islam, the religion advocates cleanliness in anything Muslims do either physically or spiritually. The Prophet Muhammad (peace be upon him) once said "Cleanliness is half of faith..." insisting that attributes such as personal hygiene, clean physical environment as well as eat clean and healthy food and beverages are desirable practices of Muslims (Shuriye, 2015). Another common feature cited as important in the judgment of service quality is the service delivery by restaurant personnel. Indeed, consumers dining experience will be enhanced by the courteousness and efficient service rendered by the staff leading to intention to revisit (Bujisic \& Hutchinson, 2015). This research is concerned with consumers' assessment of service quality from Muslim consumers' perspectives. Further studies involving a larger sample size could be carried out to determine our research propositions in Halal service quality.

\section{Acknowledgments}

The authors would like to extent their gratitude to the Ministry of Higher Education (MOHE), Malaysia, for financing the research to be undertaken successfully. The support has enabled the researchers to pursue their goals and meet the objectives of this research. Appreciation also goes to the School of Culinary Arts and Faculty of Business and Technology of UNITAR International University in providing facilities during the conduct of this research and the insight in pursue knowledge. 
INTERNATIONAL JOURNAL OF ACADEMIC RESEARCH IN BUSINESS AND SOCIAL SCIENCES

Vol. 8, No. 9, Sept. 2018, E-ISSN: 2222-6990 @ 2018 HRMARS

\section{References}

Ab Hamid, N. R., Kamari, M.N., and Saaidin, M. (2016). Perceived Service Quality of Halal Restaurants: A Study On Urban Muslim Consumers. GAI International Academic Conference Proceedings, Netherlands.

Abdul, M., Ismail, H., Hashim, H. and Johari, J. (2009). Consumer decision making process in shopping for halal food in Malaysia. US-China Business Review 8 (9), 40-47.

Abdullah, F. , Abg Abdurahman A.Z. and Hamali, J. (2012) Developing a framework of Success for the Foodservice Industry in Malaysia International Journal of Business and Society Vol. 13 No. 3 p. 309-334.

Barber, N. and Goodman, R. J. and Goh, B. K. (2011). Restaurant consumers repeat patronage: a service quality concern. International Journal of Hospitality Management 30 (2): 329-336.

Berne, J. (2004). Think-aloud protocol and adult learners. Adult Basic Education 4 (3), 153-173. Bujisic, M. and Hutchinson, J. (2015). The effects of restaurant quality attributes on customer behavioral intentions. International Journal of Contemporary and Hospitality Management, 26(8), 1270-1291.

Ericsson, K, A. and Simon, H.A.,(1984). Protocol Analysis: Verbal Reports as Data, The MIT Press, London.

Gayatri, G., Hume M. and Mort G.S. (2011) The role of Islamic Culture in service Quality research, Asian Journal on Quality, Vol. ISS : 1 p. 35 -53.

Ha, J., and Jang, S. (2010). Perceived value, satisfaction and behavioural intentions: the role of familiarity in Korean restaurants. International Journal of Hospitality Management, 29(1), 2-13. Hamdan, H., Issa, Z.M., Abu, N. and Jusoff, K. (2013). Purchasing decisions among Muslims Consumer of processed halal food products. Journal of Food Products Marketing, 19(1), 54-61. Hyun, S. S. (2010). Predictors of relationship quality and loyalty in the chain restaurant industry. Cornell Hospitality Quarterly 51 (2): 251-267.

Ibrahim. S, and Othman M. (2014) Developing and Validating Halal Service Quality Instrument for Malaysian Food Service Establishments: A conceptual paper. Elsevier Procedia - Social and Behavioral Sciences, (130) $400-408$.

Jan, M. T., Zain, O.M. and Jehangir, M.( 2011). Can Consumption Make You Happy? Exploring Students' Quality of Life from Marketing Perspective. International Journal of Economics and Management Sciences 1(1), 1 - 08.

Johns, N., Pine, R., (2002). Consumer behavior in the food service industry. a review. International Journal of Hospitality Management 21, 119-134.

Krippendorf, K. (2004). "Content analysis: an introduction to its methodology", Sage. London. Kuusela, H., and Paul, P.(2000). A comparison of concurrent and retrospective verbal protocol analysis, Academy Journal of Psychology, 113(3), 387-404.

Marinkovic, V., Senic, V., Ivkov, D., Dimitrovski, D. and Bjelic, M. (2014). The Antecedents of Satisfaction and Revisit Intentions for Full-Service Restaurants. Marketing Intelligence \& Planning, 32(3), 311-327.

Mukhtar, A. and Butt, M.M. (2012). Intention to choose Halal products: the role of religiosity. Journal of Islamic Marketing, 3(2), 108-120. 
INTERNATIONAL JOURNAL OF ACADEMIC RESEARCH IN BUSINESS AND SOCIAL SCIENCES Vol. 8, No. 9, Sept. 2018, E-ISSN: 2222-6990 @ 2018 HRMARS

Ong S.F., Chan W.C., Shorey S., Chong Y.S., Klainin-Yobasp. and He H.G. (2014). Postnatal experiences and support needs of first- time mothers in Singapore: A descriptive qualitative study.

Parasuraman, A., Zeithaml, V.A. and Berry, L.L. (1998). SERVQUAL: a multiple-item scale for measuring customer perceptions of service quality. Journal of Retail, 64(1), 14-40.

Payne, J.W., (1994). Thinking aloud: Insight into information processing. Psychological Science 5 241-248.

Pettijohn, L.S., Pettijohn, C.E., Luke, R., (1997). An evaluation of fast food restaurant satisfaction. determinants, competitive comparisons and impact on future patronage. Journal of Restaurant and Foodservice Marketing 2 (3), 3-20.

Qin, H. and Prybutok, V. R. (2009). Service quality, customer satisfaction, and behavioral intentions in fast-food restaurants. International Journal of Quality and Service Sciences 1 (1): 78-95.

Ramanathan, R., Di, Y., and Ramanathan. U. (2016). Moderating roles of customer characteristics on the link service factors and satisfaction in a buffet restaurant. Benchmarking: An International Journal, 23(2), 469-86.

Ryu, K. \& Jang, S. S. (2008) DINESCAPE: A Scale for Customers' Perception of Dining Environments. Journal of Foodservice Business Research. 11(1), 2-22

Saaidin, M., Ab Hamid, N. R. and Kamari, M.N., (2016). A Study on Perceptions Of Non-Muslim Consumers Towards Halal Food And Perceived Service Quality In Halal Restaurant. GAI International Academic Conference Proceedings, Netherlands.

Samyak, S.S. (2013). Measuring the Efficiency of Service Delivery Process In Hospitality Industry. Thesis for MBA, Christ University.

Shuriye, A.O. (2015). "The veracious construal of Halal cosmetic products and its relation to Taharah (cleanliness) and Nadhafah (hygiene and sanitation) in Islam", Vol. 6 No.6, pp 266-70.

Sivas, E., Baker-Prewitt, J.L., (2000). An examination of the relationship between service quality, customer satisfaction, and store loyalty.

Sulek, J.M. and Hensley, R.L. (2004). The relative importance of food, atmosphere and fairness of wait: the case of a full-service restaurant. Cornell Hospitality Quarterly, 45(3), 235-247.

Stevens P., Knutson B., and Patton M. (1995). Dineserv: A tool for measuring service quality in restaurants, The Cornell Hotel and Restaurant Administration Quarterly, pp 56-60.

Taib, A.T. and Gill, S.S. (2012). Socio-religious tolerance: exploring the Malaysian experience, Global Journal of Human Social Science, 12(8).

Yin, R. K. (2003). "Case Study Research: Design and Methods", 3rd ed., Sage, Thousand Oaks, CA. 